\title{
Biomonitoring evaluation of some toxic and trace elements in the sea urchin Lytechinus variegatus (Lamarck, 1816) in a marine environment: northern coast of São Paulo (Brazil)
}

\author{
Mauricio B. Alves ${ }^{1} \cdot$ Andrews A. K. Emerenciano $^{2} \cdot$ Isabella C. Bordon $^{3} \cdot$ José Roberto M. C. Silva $^{2}$. \\ Deborah I. T. Fávaro ${ }^{1}$
}

Received: 25 September 2017 / Published online: 6 December 2017

(C) Akadémiai Kiadó, Budapest, Hungary 2017

\begin{abstract}
This study aimed to evaluate the sea urchin Lytechinus variegatus as an environmental biomonitor and contribute to the knowledge of its nutritional aspects for two regions of the northern coast of the São Paulo State, Brazil. Mass fractions were determined by instrumental neutron activation analysis. Concentrations of $\mathrm{Ca}, \mathrm{Cs}, \mathrm{Cr}, \mathrm{Fe}, \mathrm{Rb}, \mathrm{Sc}$, and $\mathrm{Zn}$ were higher at Praia Grande (contaminated area), while As, Br, and Se higher at Praia Preta (control). An exploratory principal component analysis indicated that Praia Grande was influenced by $\mathrm{Cr}$, $\mathrm{Cs}$, Fe and $\mathrm{Zn}$ possibly due to environmental contamination. Results indicate the possibility of applying this organism for biomonitoring purposes for metals $\mathrm{Cr}$, Fe, $\mathrm{Zn}$ and the semimetal As.
\end{abstract}

Keywords Biomonitoring - Sea urchin · Micronutrients - Trace elements · Instrumental neutron activation analysis

\section{Introduction}

Contaminant intake in coastal environments generally occurs through domestic and industrial sewage, mining, leaching and percolation activities from landfills, ship releases, river transport, atmospheric deposition, agriculture and intensive aquaculture activities, port and marine activities, oil extraction and accidental spills of various chemicals, among others [1-4]. Contamination episodes in various coastal regions of the world have led many countries to establish extensive monitoring programs [5]. The worldwide

Electronic supplementary material The online version of this article (https://doi.org/10.1007/s10967-017-5644-9) contains supplementary material, which is available to authorized users.

Mauricio B. Alves

mbarlera@gmail.com

1 Instituto de Pesquisas Energéticas e Nucleares, IPEN CNEN/SP., Av. Professor Lineu Prestes 2242 - Cidade Universitária, São Paulo 05508-000, Brazil

2 Instituto de Ciências Biomédicas, Av. Prof. Lineu Prestes, 1524, São Paulo 05508-900, Brazil

3 Universidade Estadual Paulista Júlio de Mesquita Filho, Praça Infante Dom Henrique s/n, São Vicente, SP 11330-900, Brazil increase in pollutant levels has led to the formulation of strategies to reduce impacts on estuarine and coastal ecosystems [6]. Among these strategies is the use of cosmopolitan organisms for pollution assessments, in a strategy known as biomonitoring [7], that makes use of the ability of some organisms to absorb environmental contaminants to perform qualitative and quantitative monitoring of ecosystems $[8,9]$. Among biomonitors, bivalves have been frequently applied [10-12], although other organisms have also been assessed regarding ecotoxicological assays, such as algae, shellfish [13] and sea urchins [14].

Sea urchins are exclusively marine and benthic invertebrates, and many are sessile or display reduced mobility. They can be found in polar and tropical zones, with a wide geographic distribution $[15,16]$. The species Lytechinus variegatus (Lamarck, 1816) is widely distributed, and can be found from North Carolina, in the USA, to the Gulf of Mexico and south Brazil. They are intolerant to suspended particulate matter, leaving turbid areas. Certain cells present in this species, generically called coelomocytes, are able to respond to injuries, host invasion, and cytotoxic agents [17]. Coelomocytes are regarded as the immune effectors of the sea urchin. Spherulla cells, a type of coelomocyte, have been observed as significantly increased in animals collected from polluted seawaters and are, thus, 
considered adequate bioindicators of environmental stress [18]. Regarding environmental assessments, although this species of sea urchins has been widely used in ecotoxicological assays [19-24], little is known about the potential of these organisms as biomonitors in Brazil, however, due to the urchins lack of mobility and also to the feeding of organisms that live near the sediment, it is possible that this organism can reproduce the marine conditions of the region similar to the other biomonitors.

In the State of São Paulo, Brasil, São Sebastião, the mainland (where the city is located) and the island (known as Ilhabela) are separated by the São Sebastião Channel, about $30 \mathrm{~km}$ long with two entrances, one to the south and another to the north, with widths of about $7-6 \mathrm{~km}$, respectively [5]. This area is a center of intense tourism activity that includes the São Sebastião Port, in activity since the mid-nineteenth century. This terminal is responsible for chronic oil spills and accidents, significantly impacting the environment [25]. In the northern portion of the São Sebastião Port, located on the continental margin, is the largest and most important Brazilian petroleum terminal, the Almirante Barroso Maritime Terminal (TEBAR), located in the São Sebastião Channel.

Ilhabela is the second largest sea island in Brazil, with 44 beaches. From the east to the south, its beaches directly face the Atlantic Ocean. The west side directly faces São Sebastião City and Ports, including the TEBAR terminal. In summer, the predominant marine current causes the sea to enter the channel by north in the SW direction towards the south of the channel [26]. One of these beaches, Praia Grande, has water quality ranging from regular to poor [27]. Although water quality can be measured in terms of biological parameters originated by anthropogenic activities, other alterations can also suggest pollution by toxic metals from TEBAR, as well as others contributors, due to sea currents.

Instrumental neutron activation analysis (INAA) has been applied in several areas of knowledge and has the advantage of being a multielemental technique that requires no sample digestion. In addition, only a small amount of sample is required and limits of detection (LOD) ranging from 0.1 to $7.0 \mathrm{mg} \mathrm{kg}^{-1}$ can be obtained for the most elements $[28,29]$. In Brazil, this analytical technique has been previously used for monitoring purposes [5, 30].

In this context, the aim of the present study was to analyze $L$. variegatus sea urchin tissues from São Sebastião/Ilhabela, in southern Brazil, from a control area (Praia Preta) and a contaminated area (Praia Grande), regarding the concentration of some trace elements (As, $\mathrm{Ba}, \mathrm{Br}, \mathrm{Co}$, $\mathrm{Cr}, \mathrm{Rb}, \mathrm{Sb}$ and $\mathrm{Sc})$ and micronutrients $(\mathrm{Ca}, \mathrm{Fe}, \mathrm{K}, \mathrm{Na}, \mathrm{Se}$ and $\mathrm{Zn}$ ) by INAA. In addition, the application of this species in biomonitoring studies was also evaluated. This study intends to contribute with data on the nutritional and toxic constituents of this organism, as well as its use as a biomonitor, since scarce data is available in the literature in this regard.

\section{Experimental}

\section{Sample collection and processing}

Sea urchins of the species L. variegatus were collected in partnership with the Laboratory of Evolutionary Histophysiology at the Department of Cell Biology and Development of the Biomedical Sciences Institute of the University of São Paulo. The Marine Biology Center of the University of São Paulo was used as support base. This study was approved by the Ethical Committee on animal use from the Biomedical Sciences Institute.

Sampling was performed by means of free diving. After collection, the specimens were transferred to nylon canvas bags and subsequently to $30 \mathrm{~L}$ gallons with intermittent aeration for transport to the laboratory.

All the animals were collected under ICMBio permition (SISBIO n.30422) and in agreement with the Brazilian law [31, 32]. Samples ( $n=20$ for each site) were collected in the spring, November 2015, at two sites on the northern coast of the State of São Paulo, Praia Preta: Ilhabela (23.900034 S, $45.225448 \mathrm{~W})$, this location was chosen because it is on the east coast of the island, in the open sea and therefore was considered a control site, free from direct anthropogenic activities; and Praia Grande: São Sebastião (23.824822 S, 45.417718 W) a site with anthropogenic activities, close to the TEBAR maritime terminal. At the moment of specimen collection, temperatures were $24.0^{\circ} \mathrm{C}$ at Praia Preta and $23.3{ }^{\circ} \mathrm{C}$ at Praia Grande. Dissolved oxygen values were 3.2 and $5.1 \mathrm{mg} \mathrm{L}^{-1}$, respectively. Figure 1 displays the location of the sampling sites.

After biometric measurements (Table 1 in supplementary information), sea urchin tissues were dissected, and gonads and gut composite samples $(n=20$ organisms from each site) were stored in Falcon-type tubes. Samples were then frozen and stored in a Styrofoam box for transport to the Research Reactor Center (CRPq), Nuclear and Energy Research Institute (IPEN), São Paulo. After arrival, the samples were stored in a $-20{ }^{\circ} \mathrm{C}$ freezer until analysis.

Samples were transferred to previously sterilized Petri dishes. All material used for sample manipulation was previously soaked in a 5\% neutral Extran solution, followed by a $10 \%$ nitric acid solution and finally, washed with Milli-Q water. The drying process was performed in a ventilated oven at $40{ }^{\circ} \mathrm{C}$ until constant weight. After drying, samples were then transferred and homogenized in an agate mortar and subsequently passed through a $0.250 \mathrm{~mm}$ nylon sieve (60 mesh) and stored in polyethylene bottles. Only one replicate was made for each organism due to the 


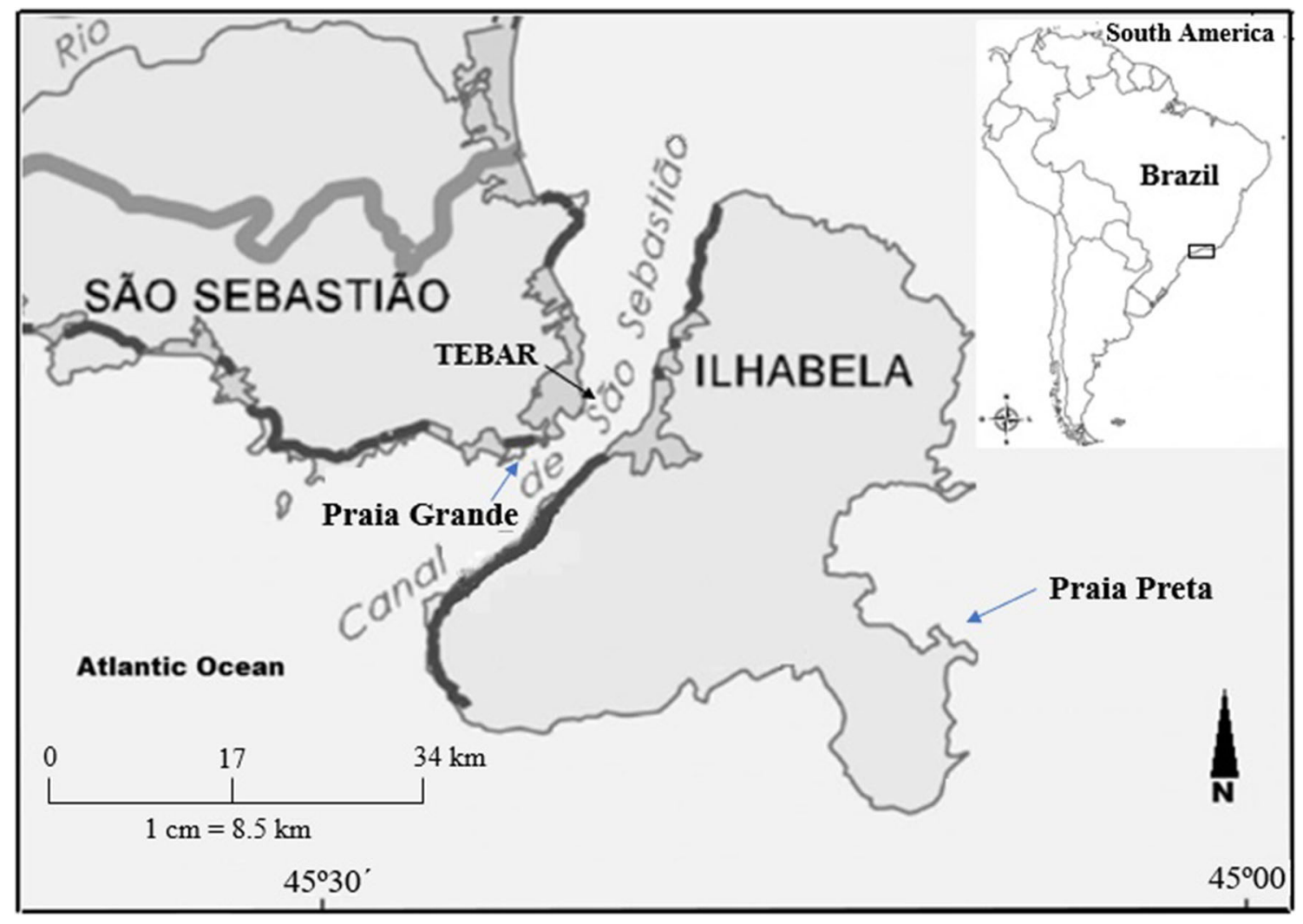

Fig. 1 Location and collection of the L. variegatus urchins at São Sebastião and Ilhabela

small amount of material available for all analyzes performed: INAA and atomic absorption spectrometry or which will be used for another assay.

\section{Red spherule count}

Absolute and relative red spherule cells counts were performed in a Neubauer chamber. An aliquot of the coelomic fluid was added to this chamber and the number of total cells was obtained by counting the cells per quadrant. This result was considered in the correlation study with the INAA analyzed chemical elements.

\section{Analytical INAA procedure}

Single and multi-element synthetic standards were prepared by pipetting aliquots of standard solutions from Assurance ${ }^{\circledR}$ Multi-Element Solution Standards (SPEX CERTIPREP, USA), onto small Whatman no. 41 filter paper sheets. $\mathrm{Ca}, \mathrm{Fe}, \mathrm{Na}$ and $\mathrm{K}$ elements were pipetted directly onto the filter paper, from the standard stock solution at $10 \mathrm{mg} \mathrm{L}^{-1}$. The other elements were diluted from the standard stock solution $\left(1 \mathrm{mg} \mathrm{L}^{-1}\right)$ with the use of calibrated volumetric flasks. The pipetted standards were then folded and placed in polyethylene bags, sealed and maintained in closed containers until analysis. These synthetic standards are important for the calculation of the $Z$-score in order to validate the certified reference materials (CRMs) for this methodology.

Two CRMs from marine organisms (mussel tissue: NIST SRM 2976 and oyster tissue: NIST SRM 1566b) were used, while the third material was chosen taking into account the number of certified reference values for several elements (peach leaves: NIST SRM 1547). Only one replicate of each CRMs was prepared for each irradiation.

Sea urchin tissue samples, four samples each time, reference materials (one sample of each one) and synthetic standards were irradiated for a daily cycle $(6-7 \mathrm{~h})$, under a thermal neutron flux of $1-5 \times 10^{12} \mathrm{~cm}^{-2} \mathrm{~s}^{-1}$ in the IEA$\mathrm{R} 1$ nuclear research reactor at IPEN. Two counting series were performed: the first, after 1 week of decay and the second, 2 weeks after irradiation, to determine $\mathrm{As}, \mathrm{Ba}, \mathrm{Br}$, $\mathrm{Ca}, \mathrm{Co}, \mathrm{Cr}, \mathrm{Cs}, \mathrm{Fe}, \mathrm{K}, \mathrm{Na}, \mathrm{Rb}, \mathrm{Sc}$, Se and $\mathrm{Zn}$ concentrations. The samples and standards were counted on a gamma ray spectrometer consisting of a hyper pure germanium semiconductor crystal detector (HPGe) associated with a CANBERRA electronic data acquisition system, with a resolution of 1.21 and $2.23 \mathrm{keV}$ for the ${ }^{57} \mathrm{Co}$ and ${ }^{60} \mathrm{Co}$ photopeaks, respectively. Data analysis was performed by using the VERSAO2 in-house software to identify the gamma-ray peaks, while the concentration results were obtained by using the Microsoft Excel ${ }^{\circledR}$ package. The 
precision and accuracy of the method were verified by mean of the CRM results and the Z-score criterion [33]. The expanded uncertainty was calculated from the error and uncertainty propagations throughout the experiment, presented in Fig. 2. Moisture content was determined for the CRMs by drying at $85{ }^{\circ} \mathrm{C}$ for $2 \mathrm{~h}$, obtaining $9.14,9.39$ and $9.49 \%$ for mussel tissue, oyster tissue, and peach leaves, respectively. These moisture content correspond to values normally found (7-9\%). In addition the $Z$-score values indicated that the standard values found are close to what was expected. Therefore the drying procedure change not brought greater uncertainties to results. The irradiation and counting procedure in the gamma spectrometer are the major contributors of uncertainties. The LOD and limits of quantification (LOQ) of the INAA technique for the analyzed elements were obtained according to [29].

\section{Statistical analyses}

In order to statistically evaluate the observed concentration variations and if these were significant or not, the ShapiroWilk test was performed to test the data set normality and the Levene test for homoscedasticity $(p<0.05$, at $95 \%$ CI). The means were tested with the independent $t$ test (by variables) where $p<0.05$ at $95 \% \mathrm{CI}$ indicates an actual concentration difference between sites. The Grubbs test (at 95\% CI) was performed for outlier detection. An exploratory principal component analysis (PCA) was applied in order to investigate separation of the study regions by the determined elements. Statistical analyses were performed using the Statistica ${ }^{\circledR}$ (ver. 13.1), Microsoft Excel ${ }^{\circledR}$ (ver. 2016), and Past ${ }^{\circledR}$ (ver. 3) softwares.

\section{Results and discussion}

As stated previously, the production of red spherule cells in sea urchins is a response to environmental stress exposure $[18,24]$. In the present study, the red spherule cell counts in organisms from Praia Grande (contaminated site) was $6.7 \pm 2.6 \%$ (mean $\pm \mathrm{SD}, 95 \%$ CI) while Praia Preta (control site) showed counts of $4.1 \pm 1.5 \%$ (mean $\pm \mathrm{SD}$, $95 \% \mathrm{CI})$. The $t$-test, $p<0.05(95 \% \mathrm{CI})$ indicated significant differences between the sites $(p=0.001)$, but no relationship was found between the spherule cells and the analyzed elements. This may indicate that the analyzed elements do not affect the amount of red spherule cells. However, these cells may be sensitive to other elements, and are especially susceptible to biological contamination. According to [18, 24] these cells act as bactericidals and play a role in inflammatory processes. Differences in the number of red spherule cells may indicate that Praia Grande is exposed to environmental stress, probably due to anthropogenic activities.

The CRM analyses were used for the validation of the INAA methodology, regarding precision and accuracy, by mean of the $Z$-criterion [33]. The results presented $|Z|<2$ values for the analyzed elements, confirming the precision and accuracy of the INAA method, except for $\mathrm{Na}$ on NIST SRM 1547 in peach leaves. For Co $Z<2$ was found only one of the three CRMs analyzed in this work, then Co results were excluded from this study. The $Z$-scores for the analyzed reference material are presented in Fig. 3.

Table 1 presents the results (mean \pm expanded uncertainty of the mean, with $k=2$ ), in dry weight (d.w.), for the analyzed sea urchin tissues by INAA in both sites. All data including combined standard uncertainty can be found in Tables 2 and 3 in supplementary information. The LOD and LOQ, number of individuals $(n)$, as well the $p$-values for the $t$-test are also presented.

Figure 4 displays box plot graphs presenting mean values for the analyzed elements at both sites. Elements $\mathrm{As}, \mathrm{Br}$ and Se presented higher mean values at Praia Preta (control), while $\mathrm{Ca}, \mathrm{Cr}, \mathrm{Co}, \mathrm{Fe}, \mathrm{Rb}, \mathrm{Sc}$ and $\mathrm{Zn}$ presented higher total mass fraction values at Praia Grande (contaminated). $\mathrm{Na}$ and $\mathrm{K}$ showed similar mean values and were not significantly different between sites. Results for $\mathrm{Ba}$ in Praia
Fig. 2 Ishikawa diagram for uncertainty contributions in the INAA method [5]

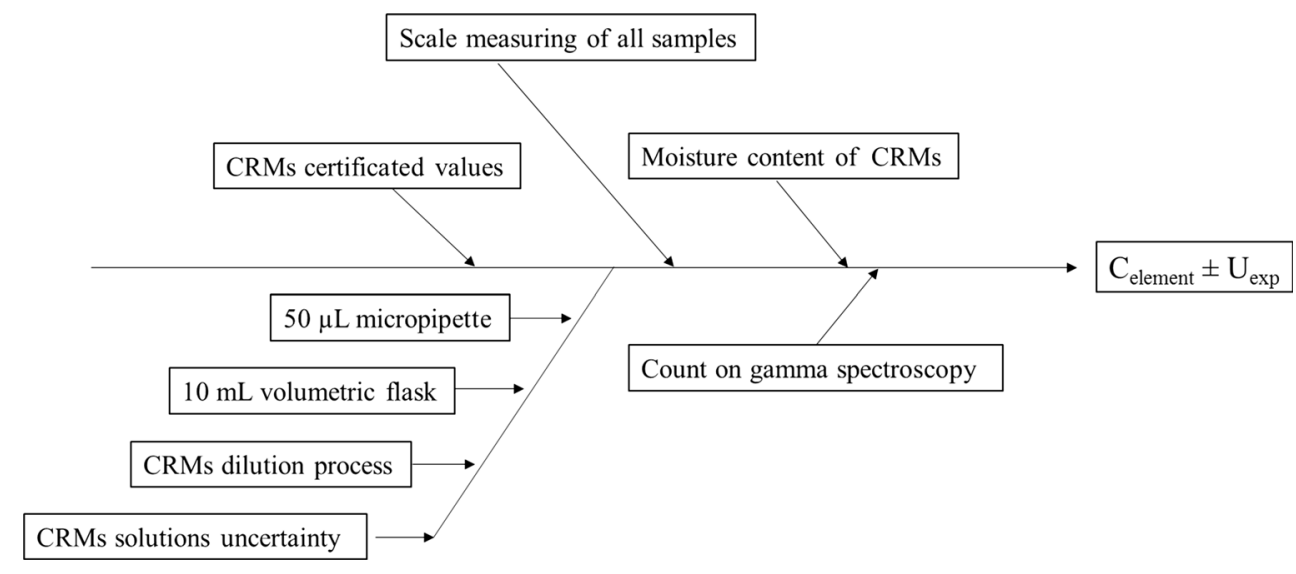


Fig. $3 \mathrm{Z}$-scores for the elements determined in the CRMs

\section{Z-score for CRMs}

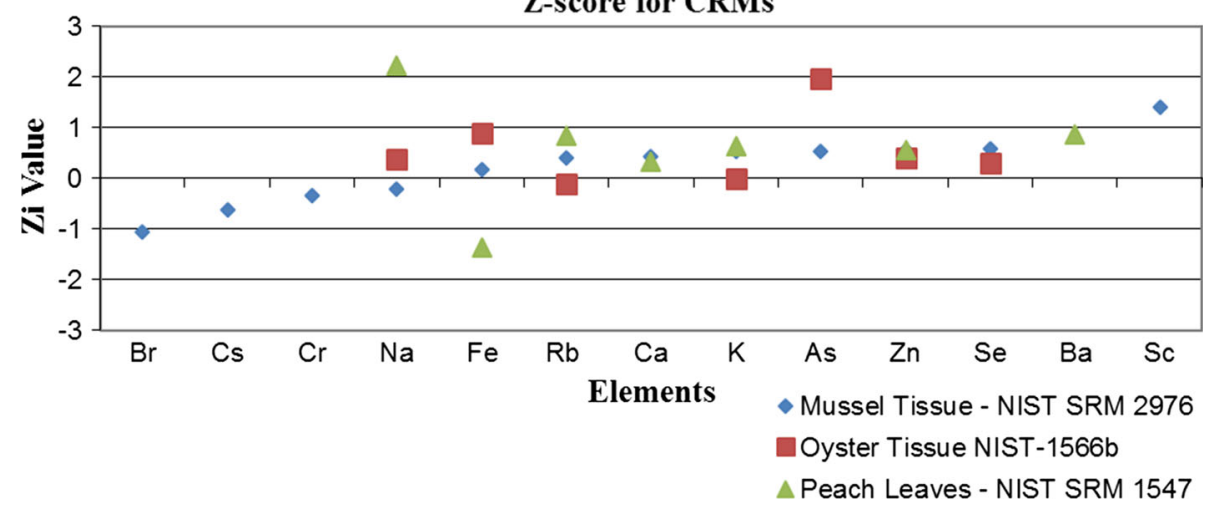

Table 1 Total mass fraction ( $\mathrm{mg} \mathrm{kg}^{-1}$, d.w.) from sea $L$. variegatus urchin tissues by INAA

\begin{tabular}{|c|c|c|c|c|c|c|c|c|c|}
\hline & \multicolumn{3}{|c|}{ Control point (Praia Preta) } & \multicolumn{6}{|c|}{ Contaminated point (Praia Grande) } \\
\hline & Mean $\pm U_{\text {exp }}$ & Range & $n^{\mathrm{b}}$ & Mean $\pm U_{\text {exp }}$ & Range & $n$ & LOD & LOQ & $p$-values \\
\hline As & $33.2 \pm 0.8$ & $(16.5-49.4)$ & 20 & $25.3 \pm 0.7$ & $(16.1-54.0)$ & 19 & 0.8 & 2.5 & 0.01 \\
\hline $\mathrm{Ba}$ & $28 \pm 12$ & $(9-52)$ & 5 & $10 \pm 3(<\mathrm{LQ})$ & $<\mathrm{LQ}$ & 4 & 3.8 & 11.4 & 0.13 \\
\hline $\mathrm{Br}$ & $514 \pm 8$ & $(223-786)$ & 20 & $300 \pm 4$ & $(196-396)$ & 19 & 0.07 & 0.21 & 0.00 \\
\hline $\mathrm{Ca}$ & $8200 \pm 2400$ & $(4497-13,407)$ & 6 & $12,100 \pm 1700$ & $(7750-17,295)$ & 11 & 1700 & 5200 & 0.04 \\
\hline $\mathrm{Cr}$ & $0.8 \pm 0.1$ & $(0.2-1.4)$ & 14 & $1.6 \pm 0.2$ & $(1.0-2.7)$ & 10 & 0.13 & 0.39 & 0.00 \\
\hline $\mathrm{Fe}$ & $1380 \pm 90$ & $(585-2341)$ & 11 & $1920 \pm 150$ & $(1340-2775)$ & 11 & 10 & 30 & 0.03 \\
\hline K & $17,800 \pm 1100$ & $(12,260-21,160)$ & 14 & $20,300 \pm 1100$ & $(14,336-31,037)$ & 15 & 1900 & 5800 & 0.12 \\
\hline $\mathrm{Na}$ & $20,000 \pm 300$ & $(14,107-25,069)$ & 18 & $23,900 \pm 300$ & $(13,700-47,350)$ & 16 & 20 & 60 & 0.11 \\
\hline $\mathrm{Rb}$ & $8 \pm 2$ & $(4.6-12.0)$ & 12 & $12 \pm 2$ & $(17.8-19.3)$ & 11 & 0.6 & 1.8 & 0.01 \\
\hline $\mathrm{Se}$ & $3.5 \pm 0.3$ & $(1.5-4.8)$ & 18 & $2.1 \pm 0.1$ & $1.4-2.9)$ & 16 & 0.1 & 0.3 & 0.00 \\
\hline $\mathrm{Zn}$ & $40 \pm 2$ & $(24-58)$ & 12 & $59 \pm 1$ & $(40-70)$ & 12 & 0.5 & 1.5 & 0.00 \\
\hline $\mathrm{Cs}^{\mathrm{a}}$ & $61 \pm 6$ & $(24-100)$ & 10 & $125 \pm 13$ & $(83-171)$ & 6 & 9 & 27 & 0.00 \\
\hline $\mathrm{Sc}^{\mathrm{a}}$ & $20 \pm 1$ & $(4-50)$ & 15 & $229 \pm 8$ & $(158-300)$ & 8 & 1.3 & 4 & 0.00 \\
\hline
\end{tabular}

$p$-value and $\mathrm{U}_{\text {exp }}$ at $95 \%$ of significance

${ }^{\text {a }}$ Total mass fraction in $\mu \mathrm{g} \mathrm{kg}-1$

${ }^{b}$ Number of results used for mean calculation

Grande did not allow the plotting of a box plot graph, since they were below the LOQ.

The $t$-Student statistical test was applied to the INAA results and confirmed the results displayed by the box plot graphs, that urchins from Praia Grande, supposedly an impacted site, presented higher levels of $\mathrm{Ca}, \mathrm{Cr}, \mathrm{Cs}, \mathrm{Fe}, \mathrm{Rb}$, $\mathrm{Sc}$, and $\mathrm{Zn}$ compared to Praia Preta $(p<0.05$, Table 1$)$. $\mathrm{As}, \mathrm{Br}$ and $\mathrm{Se}$ were present in higher significant concentrations at Praia Preta, while K and Na showed no significant differences between sites.

No statistically significant difference between the study areas ( $t$-test, $p<0.05,95 \% \mathrm{CI}$ ) was observed for $\mathrm{Na}$ at Praia Preta $\left(20,000 \pm 300 \mathrm{mg} \mathrm{kg}^{-1}\right)$ and at Praia Grande $\left(23,900 \pm 300 \mathrm{mg} \mathrm{kg}^{-1}\right)$ for $\mathrm{K}$ at Praia Preta $\left(17,800 \pm 1100 \mathrm{mg} \mathrm{kg}^{-1}\right)$ and at Praia Grande $\left(20,300 \pm 1100 \mathrm{mg} \mathrm{kg}^{-1}\right)$. Comparing these results with other organisms $[5,34]$, the sea urchin species evaluated herein is rich in $\mathrm{Na}$ and $\mathrm{K}$, but these elements are not of interest in environmental biomonitoring due to their association with salinity.

For $\mathrm{Rb}$, concentrations at Praia Preta were $8 \pm 2 \mathrm{mg} \mathrm{kg}^{-1}$ and at Praia Grande were $12 \pm 2 \mathrm{mg} \mathrm{kg}^{-1}$. Further data are needed to evaluate $\mathrm{Rb}$ for biomonitoring studies, since there is not enough data in the literature to conduct comparisons with other bentonic organisms.

Statistical $t$-test ( $p$-value $<0.05$ at $95 \% \mathrm{CI}$ ) were performed to verify whether there is a difference between the sex and to the analyzed elements and also to the collection regions. Results for the region of Praia Preta (control) showed that there were no significant differences between the sexes, except for element $\mathrm{Rb}$, whose average concentration was $6 \pm 1 \mathrm{mg} \mathrm{kg}^{-1}$ for males and $10 \pm 2 \mathrm{mg} \mathrm{kg}^{-1}$ for females. The value of $p$-value for $\mathrm{Rb}$ is 0.003 , so there 

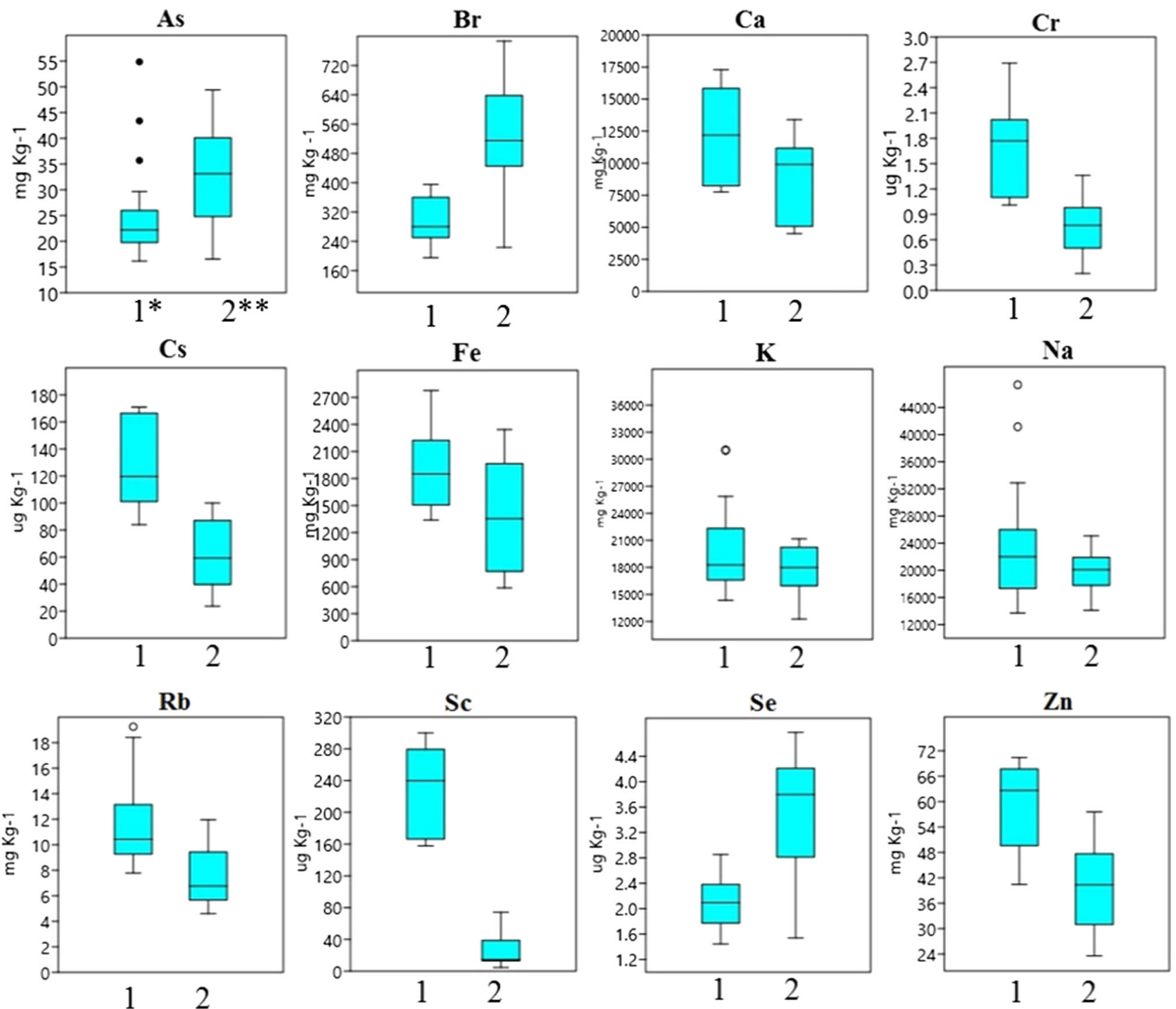

* Praia Grande (contamined site); ** Praia Preta (control site).

Fig. 4 Box plot (mean) for the elements determined by INAA (d.w.) in L. variegatus, from both the Praia Preta and Praia Grande sites

was a significant difference. In relation to the Praia Grande sea urchins, $t$-test results also indicate that there was no significant difference in concentration for the elements analyzed. However, for the $\mathrm{Rb}$ element, whose $p$-value was 0.06 , is at the limit of the significant difference which may indicate a bias of the females to have a higher $\mathrm{Rb}$ content than males, independently of the collection sites, under the conditions of this work.

An exploratory PCA, was performed with some assumptions: missing data were filled with mean values and Pearson $(r)$ values with correlation values above $|0.5|$ were considered as loading factors (Table 2). In order to verify the existence of a relationship among the elements routinely investigated in environmental biomonitoring, elements that presented no relation in the correlation matrix
Table 2 Exploratory PCA factorial for the sea urchin analyses with Pearson correlation values (values $>0.5$, bolded, were considered component factors)

\begin{tabular}{llll}
\hline & $F_{1}$ & $F_{2}$ & $F_{3}$ \\
\hline $\mathrm{As}$ & -0.037 & $\mathbf{- 0 . 8 0 7}$ & -0.183 \\
$\mathrm{Cr}$ & $\mathbf{0 . 8 9 7}$ & 0.021 & 0.166 \\
$\mathrm{Cs}$ & $\mathbf{0 . 7 2 4}$ & 0.233 & -0.068 \\
$\mathrm{Fe}$ & $\mathbf{0 . 6 7 0}$ & -0.387 & -0.207 \\
$\mathrm{Sc}$ & 0.381 & -0.178 & $\mathbf{0 . 8 5 2}$ \\
$\mathrm{Se}$ & -0.082 & $\mathbf{- 0 . 8 4 7}$ & 0.046 \\
$\mathrm{Zn}$ & $\mathbf{0 . 6 6 9}$ & 0.058 & -0.431 \\
EV $(\%)$ & 34.0 & 23.0 & 14.6 \\
\hline
\end{tabular}

$E V$ explained variance 
$(\mathrm{Ba}, \mathrm{Ca}, \mathrm{Rb})$ and high abundance elements in marine environments $(\mathrm{Br}, \mathrm{Na}$ and $\mathrm{K})$ were suppressed for the exploratory factorial PCA analysis, in order to verify if a separation of the regions by the determined elements was present. Figure 5 displays the PCA results from the $F_{1} \times F_{2}$ factors.

The PCA indicated that three main factors that influenced the investigated elements, which in total explain $71.6 \%$ of the total variance of the results. The case projection graph represented in Fig. 5, demonstrate that Factor 1 is responsible for grouping the elements that separated Praia Preta from Praia Grande.

Factor 1, that explains $34.0 \%$ of the total data variance, relates $\mathrm{Cr}, \mathrm{Cs}, \mathrm{Fe}$ and $\mathrm{Zn}$ to Praia Grande (contaminated site). The exploratory PCA analysis, $\mathrm{Cr}, \mathrm{Cs}, \mathrm{Fe}$, and $\mathrm{Zn}$, with $0.897,0.724,0.670,0.669 r$-values, respectively, indicated that these elements are more related to Praia Grande (Table 2). The environmentally relevant element in this factor, $\mathrm{Cr}$, was twofold at Praia Grande, contaminated site, $\left(1.6 \pm 0.2 \mathrm{mg} \mathrm{kg}^{-1}\right)$ compared to Praia Preta $\left(0.8 \pm 0.1 \mathrm{mg} \mathrm{kg}^{-1}\right)$. This pattern of influence for the mentioned elements, except for the Cs, corroborates with the studies done for Perna perna mussels indicating a possible anthropic source, since there are illegal housing occupations causing a worsening in the quality of the waters of the region due to clandestine sewage connections [27]. These issues could explain the increase of $\mathrm{Zn}$ concentration in relation to the control point [35]. In addition, in the TEBAR region there is high activity of oil shipments, effluents of the oil industry [5] which may be a source of these elements.

Factor 2, which explains $23.0 \%$ of the total data variance, comprises As $\left(33.2 \pm 0.8 \mathrm{mg} \mathrm{kg}^{-1}\right)$ and $\mathrm{Se}$ $\left(3.5 \pm 0.3 \mathrm{mg} \mathrm{kg}^{-1}\right)$ at Praia Preta (control site) and As

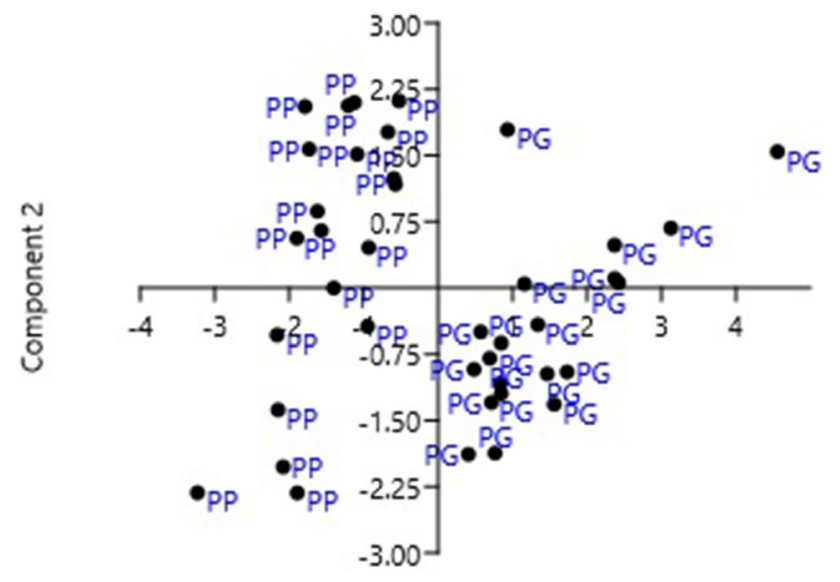

Component 1

Fig. 5 Principal component analysis $\left(F_{1} \times F_{2}\right.$ factors); $P P$ Praia Preta, $P G$ Praia Grande $\left(25.3 \pm 0.7 \mathrm{mg} \mathrm{kg}^{-1}\right)$ and $\mathrm{Se}\left(2.1 \pm 0.1 \mathrm{mg} \mathrm{kg}^{-1}\right)$ at Praia Grande (contaminated site). Significant concentration differences between both sites were observed by the $t$-test for both elements.

Factor 3, which accounts for $14.6 \%$ of the variance in exploratory PCA, reflects the high $\mathrm{Sc}$ concentrations at Praia Grande. This element was the most different between collection sites, with values of $229 \pm 8 \mu \mathrm{g} \mathrm{kg}^{-1}$ at Praia Grande and $20.3 \pm 0.8 \mu \mathrm{g} \mathrm{kg}^{-1}$ at Praia Preta. These results may suggest an anthropogenic source contribution for this element, however there is not enough data in the literature to conduct comparisons with other bentonic organisms and about biological contamination for Sc in these regions.

Table 3 presents the results obtained in the present study in comparison with other studies conducted in the same region (São Sebastião and Caraguatatuba) for sea urchins and other benthic organisms, in both control and contaminated areas.

Concerning As, the concentrations in sea urchin in the present study were much higher than those found by Catharino et al. [5] in P. perna mussels from the same region (Table 3). Quináglia [36] analyzed sediment cores from southern coast of São Paulo, specifically the Santos Estuarine System, and observed As concentrations ranging from 10 to $20 \mathrm{mg} \mathrm{kg}^{-1}$, while concentrations ranging from 5 to $10 \mathrm{mg} \mathrm{kg}^{-1}$ for As were reported by Silva et al. [37] in core sediment samples from the same estuarine region. At the Cananeia Estuarine System, located on the southern coast of São Paulo, the mean concentration for As in bottom sediment samples was around $5 \mathrm{mg} \mathrm{kg}^{-1}$ [38]. Sediment plays an important role in the benthic environment inhabited by $L$. variegatus, since urchin feeding is closer to the sediment. Thus, As concentrations in the organism can be influenced by sediment concentration.

Concerning $\mathrm{Br}$ concentrations (Table 3), this element was present in higher concentrations at Praia Preta $\left(514 \pm 8 \mathrm{mg} \mathrm{kg}^{-1}\right)$ compared to Praia Grande $\left(300 \pm 4 \mathrm{mg} \mathrm{kg}^{-1}\right) . \mathrm{Br}$ is present in sea water at about $67 \mathrm{mg} \mathrm{kg}^{-1}$ and in sediment around $60 \mathrm{mg} \mathrm{kg}^{-1}$ [37]. Differences in concentrations may be related to the availability of this element in the sea urchin food chain. There is evidence that $L$. variegatus naturally accumulates $\mathrm{Br}$, given the high concentration at both sites, since $\mathrm{Br}$ concentrations are generally high for benthic organisms, according to the study performed with $P$. perna mussels [30], presented in Table 3.

This species of urchin accumulates high amounts of $\mathrm{Ca}$ $\left(8200 \pm 2400 \mathrm{mg} \mathrm{kg}^{-1}\right.$ at Praia Preta and $12,100 \pm 1700 \mathrm{mg} \mathrm{kg}^{-1}$ at Praia Grande sites). This can be due to the fact that sea urchins use $\mathrm{Ca}$ to produce and maintain the exoskeleton, as well as the fact that Ca plays a very important role in reproduction [39]. Ca concentrations 
Table 3 Total mass fraction results (mean \pm expanded uncertainty, $k=2)\left(\mathrm{mg} \mathrm{kg}^{-1}\right)$ in sea urchins and other organisms, year of publication and references

\begin{tabular}{|c|c|c|c|c|c|c|}
\hline & Control points (mean $\pm U_{\text {exp }}$ ) & Impacted points (mean $\pm U_{\text {exp }}$ ) & Samples & Study areas & Years & References \\
\hline \multirow[t]{2}{*}{ As } & $33.2 \pm 0.8$ & $25.3 \pm 0.6$ & Urchin & São Sebastião & 2016 & This study \\
\hline & $2.74 \pm 0.04$ & $1.95 \pm 0.03$ & Mussel & & 2007 & {$[5]$} \\
\hline \multirow[t]{2}{*}{$\mathrm{Br}$} & $514 \pm 8$ & $300 \pm 4$ & Urchin & São Sebastião & 2016 & This study \\
\hline & $250 \pm 30$ & $270 \pm 30$ & Mussel & Caraguatatuba & 2012 & {$[30]$} \\
\hline \multirow[t]{3}{*}{$\mathrm{Ca}$} & $8200 \pm 2300$ & $12,000 \pm 1600$ & Urchin & São Sebastião & 2016 & This study \\
\hline & $1200 \pm 200$ & $2800 \pm 600$ & Oyster & & 2016 & [34] \\
\hline & $434 \pm 18$ & $1031 \pm 42$ & Mussel & & 2007 & {$[5]$} \\
\hline \multirow[t]{3}{*}{$\mathrm{Cr}$} & $0.8 \pm 0.1$ & $1.6 \pm 0.2$ & Urchin & São Sebastião & 2016 & This study \\
\hline & $0.4 \pm 0.1$ & $1.2 \pm 0.6$ & Oyster & & 2016 & [34] \\
\hline & $0.20 \pm 0.01$ & $0.18 \pm 0.01$ & Mussel & & 2008 & {$[5]$} \\
\hline \multirow[t]{3}{*}{$\mathrm{Fe}$} & $1380 \pm 90$ & $1900 \pm 150$ & Urchin & São Sebastião & 2016 & This study \\
\hline & $18 \pm 2$ & $58 \pm 3$ & Oyster & & 2016 & [34] \\
\hline & $27 \pm 1$ & $46 \pm 3$ & Mussel & & 2008 & {$[5]$} \\
\hline \multirow[t]{3}{*}{$\mathrm{Zn}$} & $40 \pm 2$ & $59 \pm 1$ & Urchin & São Sebastião & 2016 & This study \\
\hline & $91 \pm 18$ & $51 \pm 7$ & Oyster & & 2016 & {$[34]$} \\
\hline & $11.3 \pm 0.3$ & $13.1 \pm 0.3$ & Mussel & & 2007 & [5] \\
\hline
\end{tabular}

found in the evaluated sea urchins were much higher than those found for $P$. perna mussel and oyster tissue from the same region, at both sites (Table 3 ).

$\mathrm{Cr}$ concentrations observed herein were in the same order of magnitude as those observed in oysters, but much higher than those found in P. perna mussels, in the same region as the present study. Catharino et al. [5] suggested anthropogenic contamination regarding this element.

Regarding Fe, the concentrations observed herein were much higher than those found for oysters and mussels, while the levels in oysters and mussels organisms were of the same order of magnitude. Catharino et al. [5], while studying $P$. perna mussels, concluded that anthropogenic contribution regarding this element, due to outputs of municipal effluents, industrial effluents, the presence of TEBAR and intense boat movement [5]. The results of the present study also suggest an anthropogenic contribution for $\mathrm{Fe}$ in the region.

Concerning $\mathrm{Zn}$, the same concentration magnitude were observed in sea urchins and oysters, and higher than mussels. Studies conducted on other biomonitor organisms in the same area $[5,30,34]$ indicate higher $\mathrm{Zn}$ concentrations in impacted sites, especially in domestic sewage sludge [35] indicating possible environmental contamination.

\section{Conclusions}

The INAA technique for multi-elemental analysis allows for precise and accurate results regarding nutrients $(\mathrm{Ca}, \mathrm{Fe}$, $\mathrm{K}$, and $\mathrm{Na}$ ), micronutrients $(\mathrm{Br}, \mathrm{Se}$ and $\mathrm{Zn})$ and mineral trace elements ( $\mathrm{As}, \mathrm{Cr}, \mathrm{Cs}, \mathrm{Rb}$, and $\mathrm{Sc}$ ) concentrations.

Red spherule cell counts for the organisms from Praia Grande (contaminated site) were higher than for Praia Preta (control site). Differences in the number of red spherule cells may indicate that Praia Grande is exposed to environmental stress, probably due to anthropogenic activities.

The PCA indicated a possibility for environmental contamination for metals such $\mathrm{Cr}, \mathrm{Cs}, \mathrm{Fe}$ and $\mathrm{Zn}$ due the TEBAR activities and sewage effluents discharge. The elements As, $\mathrm{Br}$ and $\mathrm{Se}$, present in higher concentrations in sea urchins influenced Praia Preta site (control). Praia Grande (contaminated), on the other hand, presented higher concentrations for $\mathrm{Ca}, \mathrm{Cr}, \mathrm{Cs}, \mathrm{Fe}, \mathrm{Rb}, \mathrm{Sc}$ and $\mathrm{Zn}$, while $\mathrm{Ba}$, $\mathrm{K}$ and $\mathrm{Na}$ showed no significant differences between sites.

The present study contributed to knowledge on the mineral composition of the sea urchin $L$. variegatus, indicating that this species is rich in $\mathrm{As}, \mathrm{Ca}, \mathrm{Fe}, \mathrm{Na}$ and $\mathrm{K}$, when compared to other marine organisms. This study seems to indicate the possibility of applying the sea urchin L. variegatus (Lamarck, 1816) for biomonitoring purposes, mainly for the metals $\mathrm{Cr}, \mathrm{Fe}$ and $\mathrm{Zn}$ and the semi-metal As. However, further studies are required to evaluate the species biomonitoring capability with regard to other metals. 


\section{References}

1. Abessa DMS, Carr SR, Rachid BNF, Sousa ECPM, Hortelani MA, Sarkis JE (2005) Influence of a Brazilian sewage outfall on the toxicity and contamination of adjacent sediments. Mar Pollut Bull 50:875-885

2. Kennish MJ (1991) Ecology of estuaries: anthropogenic effects, 3rd edn. CRC Press, London

3. Goldburg RJ, Elliot MS, Naylor RL (2001) Environmental impacts and policy options. PEW Oceans Commission, Arlington. http://www.pewtrusts.org/uploadedFiles/wwwpewtrustsoorg/ Reports/Protecting_ocean_life/env_pew_oceans_aquaculture.pdf. Accessed 22 March 2017

4. Prósperi VA, Nascimento IA (2008) Ecotoxicological evaluation of marine and estuarine environments. In: Zagatto PA, Bertoletti E (eds) Aquatic ecotoxicology: principles and applications, 2nd edn. RIMA, São Carlos

5. Catharino MGM, Vasconcellos MBA, Sousa ECPM, Moreira EG, Pereira ACDS (2008) Biomonitoring of $\mathrm{Hg}, \mathrm{Cd}, \mathrm{Pb}$ and other elements in coastal regions of São Paulo State, Brazil, using the transplanted mussel Perna perna (Linnaeus, 1758). J Radioanal Nucl Chem 278:547-551

6. Maia CB, Almeida ACM, Moreira FR (2006) Evaluation of the lead content in mussels of the species Perna perna in the metropolitan region of the City of Rio de Janeiro. J Braz Soc Ecotoxicol 1(2):195-198

7. Conti ME (2008) Biological monitoring: theory and applications. WIT Press, Boston

8. Rainbow PS (2002) Trace metal concentrations in aquatic invertebrates: why and so what? Environ Pollut 120:497-507

9. Zhou Q, Zhang J, Fu J, Shi J, Jiang G (2008) Biomonitoring: an appealing tool for assessment of metal pollution in aquatic ecosystem. Anal Chim Acta 606:135-150

10. Boening DW (1999) An evaluation of bivalves as biomonitors of heavy metals pollution in marine waters. Environ Monit Assess 55(3):459-470

11. Ostapczuc P, Burow M, May K, Mohl C, Froning M, Subenbach B, Waidmann E, Emond H (1997) Mussel and algae as bioindicators for long-term tendencies of element pollution in marine ecosystems. Chemosphere 34(9):2049-2058

12. Bodin N, N'Gom-Kâ R, Kâ S, Thiaw OT, Morais TL, Le Loc'h F (2013) Assessment of trace metal contamination in mangrove ecosystems from Senegal, West Africa. Chemosphere 90:150-157

13. Virga RHP, Geraldo LP (2008) Investigation of heavy metal contents in species of blue siris of the genus Callinectes sp. Ciênc Tecnol Aliment 28(4):943-948

14. Chinchon S, Auernheimer C, Alastuey A, Galí S (2000) Accumulation of $\mathrm{Pb}$ and $\mathrm{Zn}$ in sea urchin plates and spines related to their different crystalline structure. Mar Pollut Bull 40:647-649

15. Pearse JS (2006) Ecological role of purple sea urchins. Science 314(5801):940-941. https://doi.org/10.1126/science.1131888

16. Ventura CRR, Lima RPN, Nobre CC, Veríssimo I, Zana PC (2006) Filo Echinodermata. In: Lavrado HP, Ignácio BL (eds) Benthic biodiversity of the central region of the Brazilian exclusive economic zone. Museu Nacional, Rio de Janeiro

17. Borges JCS, Branco PC, Pressinotti LN, Severino D, da Silva JRMC (2010) Intranuclear crystalloids of Antarctic sea urchins as a biomarker for oil contamination. Polar Biol 33:843-849

18. Pinsino A, Matranga V (2015) Sea urchin immune cells as sentinels of environmental stress. Dev Comp Immunol 49(1):198-205. https://doi.org/10.1016/j.dci.2014.11.013. Accessed 27 July 2017

19. Pusceddu FH, Alegre GF, Pereira CDS, Cesar A (2007) Evaluation of sediment toxicity of the Santos Estuary Complex employing sea urchins L. variegatus (Echinoidea: Echinodermata). J Braz Soc Ecotoxicol 2(3):237-242

20. Araújo CFC, Souza-Santos LP (2013) Use of the microalgae Thalassiosira weissflogii to assess water toxicity in the Suape Industrial-Port Complex of Pernambuco, Brazil. Ecotoxicol Environ Saf 89:212-221

21. Rodrigues SK, Abessa DMS, Machado EC (2013) Geochemical and ecotoxicological assessment for estuarine surface sediments from southern Brazil. Mar Environ Res 91:68-79

22. Sousa ECPM, Zaroni LP, Gasparro MR, Pereira CDS (2014) Review of ecotoxicological studies of the marine and estuarine environments of the Baixada Santista (São Paulo, Brazil). Braz J Oceanogr 62(2). http://dx.doi.org/10.1590/S167987592014063006202. Accessed 26 July 2017

23. Soares JB, Junior CR (2016) Echinodermata in ecotoxicological tests: maintenance and sensitivity. Braz J Oceanogr 64(1). http:// dx.doi.org/10.1590/S1679-87592016100106401. Accessed 26 July 2017

24. Emerenciano AK, Silva JRMC, Branco PC, Borges JCS (2011) Effect of echinochrome on phagocytic processes in sea urchin Lytechinus variegatus. www.teses.usp.br/teses/disponiveis/.../ AndrewsKrupinskiEmerenciano_Mestrado_I.pdf. Accessed 4 July 2017

25. Zanardi E, Bícego MC, de Miranda LB, Weber RR (1999) Distribution and origin of hydrocarbons in water and sediment in São Sebastião, SP, Brazil. Mar Pollut Bull 38(4):261-267

26. Oliveira OMP, Marques AC (2007) Dinâmica sazonal das massas de água no canal de São Sebastião, Brazil, de Março de 2005 a Maio de 2006. XII Colacmar

27. Governo do Estado de São Paulo (2014) Quality of coastal beaches in the State of São Paulo. Companhia Ambiental do Estado de São Paulo, CETESB. http://www.cetesb.sp.gov.br/agua/praias/ 25-publicacoes-/-relatorios. Accessed 4 July 2017

28. Franklin RL, Ferreira FJ, Bevilaqua JE, Fávaro DIT (2011) Assessment of metals and trace elements in sediments from Rio Grande Reservoir, Brazil, by neutron activation analysis. J Radioanal Nucl Chem 291:47-153

29. Larizzatti FE, Favaro DIT, Moreira SRD, Mazzilli BP, Piovano EL (2001) Multielemental determination by instrumental neutron activation analysis and recent sedimentation rates using ${ }^{210} \mathrm{~Pb}$ dating method at Laguna del Plata, Cordoba, Argentina. J Radioanal Nucl Chem 249(1):263-268

30. Seo D, Vasconcellos MBA, Saiki M, Catharino MGM, Moreira EG, Sousa CPM (2013) Evaluation of the levels of $\mathrm{Br}, \mathrm{Cl}, \mathrm{K}, \mathrm{Mg}$, $\mathrm{Mn}$ and $\mathrm{V}$ in Perna perna mussels collected on the coast of the State of São Paulo. In: International nuclear Atlantic conference. http://www.iaea.org/inis/collection/NCLCollectionStore/_Public/ 45/084/45084475.pdf. Accessed 2 August 2017

31. Brazil (2014) Portaria n.445, de 17 de dezembro de 2014. http:// www.icmbio.gov.br/portal/images/stories/biodiversidade/faunabrasileira/avaliacao-do-risco/PORTARIA_N\%C2\%BA_445_ DE_17_DE_DEZEMBRO_DE_2014.pdf. Accessed 17 Nov 2017

32. Brazil (2015) Portaria n.98 de 28 de Abril de 2015. http://www. icmbio.gov.br/portal/images/stories/biodiversidade/fauna-brasi leira/portarias/p_mma_98_2015_altr_p_445_2014.pdf. Accessed 17 Nov 2017

33. Bode P (1996) Instrumental and organizational aspects of a neutron activation analysis laboratory. Interfaculty Reactor Institute, Delft

34. Pezzatti RR (2014) Use of the oyster Crassostrea rhizophorea as biomonitor in the analysis of heavy metal contamination of the marine environment under the influence of the Ports of Santos and São Sebastião. https://doi.org/10.13140/RG.2.1.2173.2723

35. Bradl HB (2005) Interface science and technology, heavy metals in the environment, 1st edn. Elsevier,Neubruckle 
36. Quináglia GA (2006) Characterization of the basal levels of metal concentration. São Paulo

37. Silva PSC, Mazzilli BP, Favaro DIT (2002) Vertical distribution of minor elements and traces by analysis of instrumental neutron activation in the sediments of Santos and São Vicente Estuary. Braz J Res Dev 4(3):1141-1146
38. Amorim EP, Favaro DIT, Berbel GBB, Braga ES (2008) Assessment of metal and trace element concentrations in Cananeia Estuary, Brazil, by neutron activation and atomic absorption techniques. J Radioanal Nucl Chem 278(2):485-489

39. Payan P, Girard J, Sardet C (1990) Calcium in sea urchin egg during fertilization. Int J Dev Biol 34(1):117-125 